\title{
Neuropsychiatric features of C9orf72-associated behavioral variant frontotemporal dementia and frontotemporal dementia with motor neuron disease
}

Leonel T Takada $a^{1,2}$ and Sharon J Sha*1

\begin{abstract}
Earlier reports of chromosome 9p-linked frontotemporal dementia (FTD) with amyotrophic lateral sclerosis (ALS) kindreds observed psychosis as a prominent feature in some patients. Since the discovery of chromosome 9 open reading frame 72 (C9orf72) hexanucleotide expansions as a cause of FTD and ALS, research groups and consortia around the world have reported their respective observations of the clinical features associated with this mutation. We reviewed the recent literature on C9orf72-associated FTD and ALS with focus on the neuropsychiatric features associated with this mutation, as well as the experience at University of California, San Francisco. The results and methodologies varied greatly across studies, making comparison of results challenging. Four reports found that psychotic features (particularly delusions) were frequent among mutation carriers, particularly when present early during the disease course, suggesting that this symptom category may be a marker for the mutation. Disinhibition and apathy were the most commonly reported early behavioral symptoms, but these may not be helpful in distinguishing carriers and noncarriers because of the symptoms'frequency in sporadic behavioral variant FTD. Other neuropsychiatric features were reported in different frequencies across studies, suggesting either a similar behavioral phenotype in carriers and noncarriers or reflecting the heterogeneity in clinical presentation of behavioral variant FTD due to C9orf72 expansions. Further studies with larger cohorts will be necessary to determine the neuropsychiatric presentation associated with this mutation.
\end{abstract}

\section{Introduction}

Only recently has the overlap between psychiatry and neurology been more thoroughly explored. Among all neurodegenerative disorders, frontotemporal dementia (FTD) particularly distinguishes itself because behavioral changes are the hallmark of this group of disorders. Approximately $50 \%$ of patients with behavioral variant FTD (bvFTD) receive a psychiatric diagnosis (most frequently major depressive disorder, schizophrenia, and bipolar disorder) prior to correct diagnosis [1]. Understanding the manner in which bvFTD may present as a neuropsychiatric syndrome is paramount to avoid erroneous diagnoses and provide the best treatment for patients.

*Correspondence: sharon.sha@ucsf.edu

'University of California, San Francisco Memory and Aging Center, Box 1207,

San Francisco, CA 94143-1207, USA

Full list of author information is available at the end of the article
A hexanucleotide repeat expansion in chromosome 9 open reading frame 72 (C9orf72) [GenBank:JN681271] was recently discovered to probably be the most frequent genetic cause of bvFTD, FTD with motor neuron disease (FTD-MND) and amyotrophic lateral sclerosis (ALS) $[2,3]$. The mean age at onset of symptoms has been reported to be approximately 56 years [4-6], ranging from the fourth to the ninth decade [5,7]. bvFTD, FTD-MND and ALS are the most commonly observed phenotypes, but nonfluent variant primary progressive aphasia, Alzheimer's disease, parkinsonism, corticobasal syndrome, and ataxia have also been reported, albeit infrequently $[4,6,8-10]$. Although the majority of patients with C9orf72 expansions have a positive family history of FTD and/or MND [6], approximately 6\% of sporadic cases of bvFTD are also due to this mutation [11].

Earlier reports of chromosome 9p-linked families described patients with psychotic features (hallucinations or delusions) [12-15], suggesting that these symptoms could be markers of this mutation. The first studies to 
describe the phenotype associated with C9orf72 expansions at a group level therefore sought to characterize the neuropsychiatric features associated with this mutation.

In this review, we will consider the neuropsychiatric features associated with bvFTD (with or without MND) due to mutations in C9orf72, based on the literature published since September 2011, presenting available data from cohorts of mutation carriers.

\section{Methods}

We reviewed papers published and/or listed on PubMed prior to 1 May 2012, using the search term 'C9orf72'. We included in this review studies on cohorts of C9orf72 mutation carriers that presented data on neuropsychiatric symptoms of any kind. Case reports, reviews and/or editorials were excluded. We gathered information on whether the behavioral features were present early in the disease course (early behavioral features) or anytime during the course of disease. Symptoms reported as 'first (neuropsychiatric) symptoms' [5], 'at initial referral' [4] or at 'first assessment' [6], in the setting of 'initial clinical presentation' [16], or occurring within the first year of disease [17] were considered early behavioral features. Symptoms reported without mention of timing $[7,18]$, in the 'last assessment' [6], or in the 'final year' [17] were considered present during the disease course.

Studies varied greatly in methodology (Table 1) - that is, use of a noncarrier control comparison group or not, methodology of ascertainment of symptoms, and so forth - limiting direct comparisons between cohorts and drawing definite conclusions at this point. When available, data from carriers with bvFTD will be presented separately from those for carriers with FTDMND, as prior studies have suggested that the neuropsychiatric symptoms of FTD with MND might be distinct from FTD without MND [19]. Because studies of chromosome 9p-linked families and several C9orf72 cohort descriptions $[4,5,7,12-15,20]$ suggested that psychosis (as defined by the presence of delusions or hallucinations of any type) might be a distinguishing feature of this mutation, data on psychotic symptoms will be presented separately; other symptoms will be discussed based on timing.

\section{Results}

Twenty-two manuscripts were initially identified. Of those articles, four were reviews, three were case reports and two were editorials, and all nine studies were therefore excluded. Five papers were excluded because behavioral features were not reported. One study reported psychiatric symptoms in seven (of 20) mutation carriers [9]. Psychiatric symptoms in that paper included depression, delusions, hallucinations and paranoia, and were considered 'not uncommon' among carriers with
ALS and frontotemporal lobar degeneration with MND. Because no further analysis or description was conducted, the paper was excluded from this review.

As a result, seven papers were included $[4,6,7,16,17$, $20,21]$. We also included a paper with the results from our center [5]. The diagnostic make-up and methodology for behavioral symptom assessment are presented in Table 1. Only one study analyzed bvFTD and FTD-MND separately (Table 1) [5].

\section{Psychotic symptoms}

Seven studies reported psychotic features among C9orf72 expansion carriers. Delusions were reported in 0 to $45 \%$ of patients and hallucinations in 0 to $50 \%$ (Table 1). An important point to note is that only two studies compared the frequency of psychosis among carriers with FTD against a group of noncarriers $[4,5]$.

Prominent psychotic symptoms were observed in carriers as early manifestations by Snowden and colleagues [4]. They reported these symptoms in $12 / 32$ patients (38\%) with C9orf72 expansion (contrasting with $<4 \%$ among noncarriers, which was a statistically significant difference), leading to initial diagnoses of delusional psychosis, somatoform psychosis, or paranoid schizophrenia'. At the time of referral, 16/32 patients had developed delusions, which were somatic in nature (that is, altered temperature perception, preoccupation with bowel movements, leg pain, and so forth) in eight of those patients. The authors also observed that none of the patients with delusions had a prior history of psychiatric conditions, which differed from those without the mutation. Hallucinations were reported in six carriers $(19 \%)$ at the time of referral.

Psychotic symptoms were also frequent in our group [5]. Delusions were more frequently reported as the first neuropsychiatric symptoms among bvFTD patients with the C9orf72 mutation (21\%) than among sporadic noncarriers (0\%). In FTD-MND, however, carriers and noncarriers had similar frequencies of delusions as first symptoms ( $18 \%$ and $11 \%$, respectively). Delusions were usually of paranoid type, and frequently involved the patients' spouses, such as claiming the partner was cheating or tricking the patient. The type of delusion in our cohort did not seem to differentiate carriers and noncarriers, and somatic delusions such as those reported by Snowden and colleagues were not observed among carriers in our cohort. Visual hallucinations were not reported as early neuropsychiatric symptoms in C9orf71-associated disease and, at first evaluation, were infrequent (Table 1). There were no auditory hallucinations. Interestingly, using the Neuropsychiatric Inventory [22] at first evaluation, the difference in delusions between carriers and noncarriers was no longer present, suggesting that, in this cohort, delusions could be specific 
Table 1. Neuropsychiatric features reported in C9orf72 expansion carriers

\begin{tabular}{|c|c|c|c|c|c|c|c|c|c|}
\hline & UCSF MAC & & $\begin{array}{l}\text { Snowden } \\
\text { and } \\
\text { colleagues } \\
{[4]}\end{array}$ & $\begin{array}{l}\text { Mahoney } \\
\text { and } \\
\text { colleagues } \\
{[6]}\end{array}$ & $\begin{array}{l}\text { Hsiung } \\
\text { and } \\
\text { colleagues } \\
{[17]}\end{array}$ & $\begin{array}{l}\text { Boeve } \\
\text { and } \\
\text { colleagues } \\
\text { [7] }\end{array}$ & $\begin{array}{l}\text { Chio } \\
\text { and } \\
\text { colleagues } \\
{[20]}\end{array}$ & $\begin{array}{l}\text { Simón- } \\
\text { Sanchez and } \\
\text { colleagues } \\
\text { [23] }\end{array}$ & $\begin{array}{l}\text { Byrne } \\
\text { and } \\
\text { colleagues } \\
{[18]}\end{array}$ \\
\hline \multirow[t]{3}{*}{ Phenotype of carriers ${ }^{b}$} & 14 bvFTD & & $\begin{array}{l}19 \text { bvFTD, } \\
1 \mathrm{SD} / \mathrm{FTD} \\
3 \mathrm{PNFA}\end{array}$ & $\begin{array}{l}12 \text { bvFTD, } \\
1 \text { PNFA }\end{array}$ & 15 bvFTD & 16 bvFTD & - & $\begin{array}{l}28 \text { bvFTD } \\
7 \text { PPA }\end{array}$ & - \\
\hline & & 11 FTD-MND & 9 FTD-MND & 3 FTD-MND & 7 FTD-MND & 3 FTD-MND & 30 FTD-MND & $\begin{array}{l}6 \text { FTD-MND, } \\
1 \text { PPA-MND }\end{array}$ & 10 FTD-MND \\
\hline & & & & & $8 \mathrm{ALS}$ & $1 \mathrm{ALS}$ & $36 \mathrm{ALS}$ & - & $11 \mathrm{ALS}$ \\
\hline Controls (noncarriers) ${ }^{c}$ & 45 bvFTD & 19 FTD-MND & $\begin{array}{l}366 \\
\text { noncarriers }\end{array}$ & NA & NA & NA & $N A^{d}$ & NA & $\begin{array}{l}166 \mathrm{ALS} \\
( \pm \text { FTD })\end{array}$ \\
\hline Number screened & 648 & & 398 & 234 & 22 & 604 & 182 & 363 & 435 \\
\hline Assessment method & $\begin{array}{l}\text { RCR and } \\
\mathrm{NPI}\end{array}$ & & $\begin{array}{l}\text { Structured } \\
\text { pro-forma }\end{array}$ & $\mathrm{RCR}$ & $\mathrm{RCR}$ & $\mathrm{RCR}$ & $\begin{array}{l}\text { FSBS and } \\
\text { RCRe }^{\text {e }}\end{array}$ & $\mathrm{RCR}$ & FSBS \\
\hline Disinhibition & $85 \%$ & $63 \%$ & $66 \%$ & $63 \rightarrow 76 \%$ & $40 \rightarrow 70 \%$ & NA & $13 \% \mathrm{e}^{\mathrm{e}}$ & $26 \%$ & NA \\
\hline Apathy/inertia & $64 \%$ & $36 \%$ & $88 \%$ & $49 \rightarrow 63 \%$ & $30 \rightarrow 47 \%$ & NA & $100 \%$ e & $43 \%$ & NA \\
\hline $\begin{array}{l}\text { Loss of sympathy/ } \\
\text { empathy }\end{array}$ & $57 \%$ & $45 \%$ & $77 \%$ & $\sim 12 \rightarrow \sim 18 \%$ & NA & NA & NA & NA & NA \\
\hline $\begin{array}{l}\text { Perseverative/ } \\
\text { compulsive behavior }\end{array}$ & $\begin{array}{l}50 \% \text { repet., } \\
50 \% \text { comp. }\end{array}$ & $\begin{array}{l}18 \% \text { repet., } \\
54 \% \text { comp. }\end{array}$ & $\begin{array}{l}75 \% \text { repet./ } \\
\text { stereotypic }\end{array}$ & $\begin{array}{l}\sim 25 \rightarrow 50 \% \\
\text { obsessive }\end{array}$ & $\begin{array}{l}27 \rightarrow 50 \% \\
\text { rigidity / } \\
\text { persev. }\end{array}$ & NA & $\begin{array}{l}1.5 \% \text { acute } \\
\text { OCD }\end{array}$ & $12 \% \mathrm{OCD}$ & NA \\
\hline Hyperorality & $50 \%$ & $27 \%$ & $43 \%$ & NA & NA & $100 \%$ & NA & NA & NA \\
\hline Anxiety & NA & NA & NA & $\sim 39 \rightarrow 52 \%$ & NA & NA & NA & NA & NA \\
\hline Delusions & $42 \%$ & $36 \%$ & $50 \%$ & $0 \rightarrow \sim 12 \%$ & $3 \%$ & $45 \%$ & $4 \%^{f}$ & 0 & NA \\
\hline Hallucinations & $7 \%$ & $9 \%$ & $19 \%$ & $\sim 6 \rightarrow \sim 12 \%$ & 0 & $50 \%$ & $4 \%^{f}$ & $5 \%$ & NA \\
\hline Lack of insight & NA & NA & $78 \%$ & NA & NA & NA & NA & NA & NA \\
\hline
\end{tabular}

Reported at first assessment (UCSF MAC and [4,23]), during course of disease [7,20] or at first and final evaluation [6,17]. Byrne and colleagues did not report frequencies [18]. Number before arrow, frequency at first assessment; number after arrow, frequency at last assessment. ALS, amyotrophic lateral sclerosis; bvFTD, behavioral variant frontotemporal dementia; comp., compulsive; C9orf72, chromosome 9 open reading frame 72; FSBS, Frontal Systems Behavior Scale; FTD, frontotemporal dementia; MND, motor neuron disease; NA, not available; NPI, Neuropsychiatric Inventory; OCD, obsessive-compulsive disorder; persev., perseverative; PNFA, progressive nonfluent aphasia; PPA, primary progressive aphasia; RCR, retrospective chart review; repet., repetitive; SD, semantic dementia; UCSF MAC, University of California, San Francisco Memory and Aging Center. aased on data collected for Sha and colleagues [5], but not included in the final manuscript. ${ }^{b}$ Number of patients included in symptom frequency analysis. ' Controls used for comparison of clinical features. ${ }^{\mathrm{d}}$ Fifty-seven carriers with other ALS-causing mutations

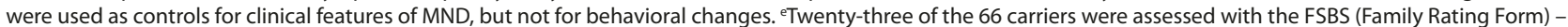
percentages reflect only those evaluated with the scale. ${ }^{\text {fFrequency }}$ of psychosis (hallucinations and/or delusions were reported in three out of 66 patients).

to C9orf72 mutations only if reported as first symptoms rather than at first evaluation.

Boeve and colleagues reported delusions in $45 \%$ and hallucinations in $50 \%$ of 20 carriers with bvFTD, FTDMND, and ALS, but those symptoms were not further detailed [7]. In their cohort, delusions and hallucinations were present in two out of three patients with FTD-MND.

Carriers with ALS were also noted to have psychotic symptoms. In a cohort of familial ALS (with or without FTD), Chio and colleagues reported three probands with prominent delusions and/or hallucinations (in the context of FTD-MND), stating that psychotic symptoms were more common among carriers than noncarriers with familial ALS [20]. However, ALS patients with C9orf72 expansions were also more likely to develop cognitive impairment (that is, FTD) than carriers of other ALS-causing mutations (such as FUS, TARDBP, SOD1 and unknown genes), making it less clear whether psychosis was associated with the mutation or was only associated with the presence of cognitive impairment.

In contrast, three studies found lower numbers of carriers with psychotic symptoms. Although SimónSanchez and colleagues noted hallucinations (visual or auditory), this occurred only in two out of 42 mutation carriers and none had delusions [23]. Mahoney and colleagues reported delusions and hallucinations in only approximately $10 \%$ of patients with C9orf 72 expansions [6]. Delusions were late manifestations of disease, and were not observed in the initial assessment in any carrier, whereas hallucinations were reported in about one-half of patients at the first assessment. Hsiung and colleagues reported one bvFTD mutation carrier out of 30 that presented with delusions, who was initially diagnosed with psychosis/schizophrenia [17]. 


\section{Early neuropsychiatric symptoms}

Apathy and disinhibition were common early neuropsychiatric symptoms in many cohorts (Table 1) [5,17,24]. Although these symptoms are hallmarks of bvFTD and are included in the diagnostic criteria (disinhibition, apathy/inertia, loss of sympathy and/or empathy, perseverative or compulsive behavior, and eating behavior changes) [25], other symptoms, such as depression or anxiety, were also found to be frequent among carriers in some studies. The most frequent symptoms were highly variable across studies. For example, Mahoney and colleagues found that anxiety (33\%) and disinhibition (13\%) were the most commonly reported initial behavioral changes [6]. Hsiung and colleagues observed that carriers developed, in the first year of disease, disinhibition (40\%), apathy (30\%), rigidity/perseveration (27\%) and depression (13\%) [17]. Simón-Sanchez and colleagues found in the 34 carriers diagnosed with bvFTD that the initial clinical presentation was apathy in $53 \%$, disinhibition in $32 \%$, and obsessive-compulsive behavior in 15\% [23]. Obsessive-compulsive disorder was also reported in one carrier from the study by Chio and colleagues [20].

Only one study compared the first neuropsychiatric features of carriers and noncarriers with bvFTD and FTD-MND separately [5], and statistically significant differences were not found. In C9orf72-associated bvFTD, apathy (50\%), obsession (28.5\%) and delusions (21\%) were the most common first neuropsychiatric symptoms. Aggression, depression and irritability were reported in $14.2 \%$ of cases. Carriers with FTD-MND presented disinhibition (36.3\%), rash/careless actions (27.2\%), apathy (18.1\%) and delusions $(18.1 \%)$.

\section{Neuropsychiatric symptoms reported during the course of disease}

As expected, the most frequently reported behavioral symptoms in cohorts with C 9 orf 72 mutations are those also used in the FTD research diagnostic criteria [25]. Across all studies that reported neuropsychiatric symptoms in patients carrying this mutation, apathy and disinhibition were again the most frequently observed (Table 1), but frequencies varied considerably across studies. Using the Frontal Systems Behavioral Scale $[19,26,27]$, Byrne and colleagues found higher apathy scores in carriers than in noncarriers (but disinhibition scores were not different) [18]. In the study by Sha and colleagues, however, neither the apathy or disinhibition subscores from the Neuropsychiatric Inventory were significantly different [5]. In Table 1 the frequencies are reported during the course of disease and/or at last assessment in mutation carriers.

In the study by Snowden and colleagues, repetitive/ stereotypic behaviors were commonly characterized by complex routines, sometimes associated with obsessive symptoms, while simple motor behaviors were infrequent $[4,6]$.

Regarding eating behaviors, Snowden and colleagues found that mutation carriers in their cohort had less dietary changes than noncarriers [4]. This was mostly due to decreased preference for sweet foods rather than changes in food intake. We found a similar pattern in our cohort, as mutation carriers with bvFTD had milder eating behaviors than noncarriers as noted on the Neuropsychiatric Inventory at first evaluation in our cohort [5]. In contrast, Boeve and colleagues reported appetite/eating behavior changes in all mutation carriers from whom information was available [7]. Altered eating behaviors are common in bvFTD, and have been associated with pathology for frontotemporal lobar degeneration with TDP-43 positive inclusions (FTLDTDP) [28], so no conclusions regarding C9orf72 and these behaviors can be reached at this point.

\section{Conclusion}

We reviewed the neuropsychiatric features observed in the recently discovered $C 90 r f 72$ mutation and found seven studies from major FTD and/or ALS groups or consortia that included these features. The number of carriers in the available studies was relatively small and most studies did not systematically compare behavioral symptoms in mutation carriers with noncarriers, thus limiting the conclusions on whether there are distinguishing features specific to the mutation. In addition, direct comparison across studies is difficult due to significant variation in results, data collection methodology, and means of reporting data.

Psychosis was often reported in studies as an early neuropsychiatric feature in C9orf72-associated bvFTD. In fact, both studies that compared this behavioral feature among expansion carriers with a group of noncarriers found that psychosis was more frequent among carriers. However, this finding was not consistent across groups and there was a broad range of frequencies of psychotic symptoms among carriers. Most studies were retrospective chart reviews, which could explain the variation across studies in part, as some neuropsychiatric features might be underestimated. In addition, the cohorts were relatively small (all cohorts had less than 67 carriers), which could substantiate this variability. Studies with larger cohorts to determine more reliably the frequency of psychosis are needed. Molecular and pathological characteristics of the cohorts could also be different, leading to different experiences across groups. The number of hexanucleotide repeats, which is not currently quantifiable [2], could be a source of phenotypical heterogeneity. The neuropathological findings associated with this mutation are also heterogeneous. 
While ubiquitin/p62-positive inclusions in the cerebellar granule cell layer appear to be specific of this mutation, they are found in most, but not all, cases $[6,7,17]$. The distribution of TDP-43 pathology may be consistent with FTLD-TDP types A or B, or may show mixed features of both types [6,7,17]. Different frequencies of TDP pathology types could explain the disparity in findings: FTD-MND and its underlying pathological finding, FTLD-TDP type B, have also been linked to psychotic features $[19,26]$. In the cohort characterized by our group, only carriers diagnosed with bvFTD had a higher frequency of delusions, without a statistically significant difference between carriers and noncarriers with FTDMND [5]. Conversely, Snowden and colleagues reported delusions in only one noncarrier with the FTD-MND phenotype [4], suggesting that this symptom type was associated with the mutation rather than with pathology.

The neuroanatomical basis of delusions in FTD is yet to be clearly characterized [29], and additional analyses of C9orf72 may further develop this knowledge. Thalamic and cerebellar atrophy have been reported in mutation carriers [5,6], and Mahoney and colleagues hypothesized that thalamic and cerebellar projections could be related to the neuropsychiatric features associated with this mutation, including hallucinations and/or delusions [6].

One should note that although psychosis is considered rare in bvFTD [30], it is not specific to this mutation and has been also reported with a higher frequency in patients diagnosed with the FTD-MND phenotype and those with atypical frontotemporal lobar degeneration with FUS pathology. Lillo and colleagues found that delusions were present in $50 \%$ of patients diagnosed with FTD-MND (not tested for C9orf72 expansion), which was significantly more frequent than in patients with bvFTD without MND (19\%) [19]. They observed a variety of delusions, including somatic and persecutory delusions. The frequency of hallucinations was not different between groups, however. Urwin and colleagues reported that $36 \%$ of patients presenting a subtype of FTLD with FUS pathology, termed atypical FTLD-U, had hallucinations or delusions [31]. The age at onset of symptoms in this group was younger than observed in bvFTD due to C9orf72 expansions. Psychosis has also been reported in patients with bvFTD carrying other mutations, although no studies have shown higher frequencies of psychotic symptoms among carriers of other FTDcausing mutations when compared with a group of noncarriers. Le Ber and colleagues reported hallucinations in $25 \%$ of progranulin gene GRN mutation carriers [32] (although other groups did not find similarly high frequencies of this symptom [33]). Johnson and colleagues reported psychotic features in one patient with a valosincontaining protein gene VCP mutation [34]. Psychosis has only infrequently been reported in families with microtubule-associated protein tau gene MAPT mutations $[35,36]$.

Apathy and disinhibition were also frequently seen in mutation carriers. However, these symptoms are also common in sporadic bvFTD and are unlikely to distinguish carriers from noncarriers. Other behavioral features were variably reported during the course of disease (Table 1) without a discernible pattern that can be attributed to the C9orf72 expansions at this point. For example, eating behavior changes were suggested to be less common among carriers in two studies [4,5], but in another study were observed in $100 \%$ of carriers [7]. The lack of substantial differences by genotype could indicate that overall the neuropsychiatric presentation associated with the mutation is similar to sporadic patients. This lack of difference could also reflect the heterogeneity seen in the clinical presentation of C9orf72 expansion carriers with bvFTD (with or without MND), leading to varying results in different groups (particularly considering the size of the samples reported in each study). Some patients, for example, may develop subtle behavioral changes years or decades before being diagnosed with dementia [37], a feature that may not be captured in group-based studies.

Although imaging is not the focus of this review, it is noteworthy that a fraction of patients with FTD due to C9orf72 mutations may have minimal atrophy on neuroimaging $[7,38]$, which is another aspect of the heterogeneity associated with this mutation. Interestingly, among five patients with bvFTD who presented with psychotic symptoms, Velakoulis and colleagues reported minimal macroscopic atrophy in two (one patient with FTD-MND pathology, and the other patient with FTD and MND-type inclusions on autopsy) [26]. Atrophy on neuroimaging is sometimes used in clinical practice as a way to distinguish neurodegenerative conditions from those considered primarily psychiatric, so patients with this mutation who present with prominent neuropsychiatric symptoms and have little to no changes on neuroimaging may be particularly prone to being misdiagnosed [38].

In summary, delusions and hallucinations might be markers of C9orf72-associated disease, but studies with larger cohorts are needed to further substantiate this affirmation. The overall neuropsychiatric presentation of this mutation appears to be similar to sporadic disease in regard to typical bvFTD symptoms, but its presentation is heterogeneous and a subset of mutation carriers may be at higher risk of being misdiagnosed with primary psychiatric conditions.

\section{Abbreviations}

ALS, amyotrophic lateral sclerosis; bvFTD, behavioral variant frontotemporal dementia; C9orf72, chromosome 9 open reading frame 72; FTD,

frontotemporal dementia; FTLD-TDP, frontotemporal lobar degeneration with TDP-43 positive inclusions; MND, motor neuron disease. 


\section{Competing interests}

The authors declare that they have no competing interests.

\section{Acknowledgements}

Data shown in this manuscript include information collected through research funded by the Larry L. Hillblom Foundation, the Consortium for Frontotemporal Dementia Research, the John Douglas French Alzheimer's Foundation, the Tau Consortium, NIH grants P50AG023501, P01AG019724 and P50 AG1657303, the State of California, and the Alzheimer's Disease Research Center of California grant 03-7527.

\section{Author details}

'University of California, San Francisco Memory and Aging Center, Box 1207, San Francisco, CA 94143-1207, USA. ²Department of Neurology, University of São Paulo, Av. Dr. Enéas de Carvalho Aguiar, 255, room 5084, Sao Paulo, SP 05403-900, Brazil.

\section{Published: 3 October 2012}

\section{References}

1. Woolley JD, Khan BK, Murthy NK, Miller BL, Rankin KP: The diagnostic challenge of psychiatric symptoms in neurodegenerative disease: rates of and risk factors for prior psychiatric diagnosis in patients with early neurodegenerative disease. J Clin Psychiatry 2011, 72:126-133.

2. DeJesus-Hernandez M, Mackenzie IR, Boeve BF, Boxer AL, Baker M, Rutherford NJ, Nicholson AM, Finch NA, Flynn H, Adamson J, Kouri N, Wojtas A, Sengdy P, Hsiung G-YR, Karydas A, Seeley WW, Josephs KA, Coppola G, Geschwind DH, Wszolek ZK, Feldman H, Knopman DS, Petersen RC, Miller BL, Dickson DW, Boylan KB, Graff-Radford NR, Rademakers R: Expanded GGGGCC hexanucleotide repeat in noncoding region of C9ORF72 causes chromosome 9p-linked FTD and ALS. Neuron 2011, 72:245-256.

3. Renton AE, Majounie E, Waite A, Simón-Sánchez J, Rollinson S, Gibbs JR, Schymick JC, Laaksovirta H, van Swieten JC, Myllykangas L, Kalimo H, Paetau A, Abramzon Y, Remes AM, Kaganovich A, Scholz SW, Duckworth J, Ding J, Harmer DW, Hernandez DG, Johnson JO, Mok K, Ryten M, Trabzuni D, Guerreiro RJ, Orrell RW, Neal J, Murray A, Pearson J, Jansen IE, et al.: A hexanucleotide repeat expansion in C9ORF72 is the cause of chromosome 9p21-linked ALS-FTD. Neuron 2011, 72:257-268.

4. Snowden JS, Rollinson S, Thompson JC, Harris JM, Stopford CL, Richardson AMT, Jones M, Gerhard A, Davidson YS, Robinson A, Gibbons L, Hu Q, DuPlessis D, Neary D, Mann DMA, Pickering-Brown SM: Distinct clinical and pathological characteristics of frontotemporal dementia associated with C9ORF72 mutations. Brain 2012, 135:693-708.

5. Sha SJ, Takada LT, Rankin KP, Yokoyama JS, Rutherford NJ, Fong JC, Khan B, Karydas A, Baker MC, DeJesus-Hernandez M, Pribadi M, Coppola G, Geschwind DH, Rademakers R, Lee SE, Seeley W, Miller BL, Boxer AL: Frontotemporal dementia due to C9ORF72 mutations: clinical and imaging features. Neurology 2012, 79:1002-1011.

6. Mahoney CJ, Beck J, Rohrer JD, Lashley T, Mok K, Shakespeare T, Yeatman T, Warrington EK, Schott JM, Fox NC, Rossor MN, Hardy J, Collinge J, Revesz T, Mead S, Warren JD: Frontotemporal dementia with the C9ORF72 hexanucleotide repeat expansion: clinical, neuroanatomical and neuropathological features. Brain 2012, 135:736-750.

7. Boeve BF, Boylan KB, Graff-Radford NR, DeJesus-Hernandez M, Knopman DS, Pedraza O, Vemuri P, Jones D, Lowe V, Murray ME, Dickson DW, Josephs KA, Rush BK, Machulda MM, Fields JA, Ferman TJ, Baker M, Rutherford NJ, Adamson J, Wszolek ZK, Adeli A, Savica R, Boot B, Kuntz KM, Gavrilova R, Reeves A, Whitwell J, Kantarci K, Jack CR, Parisi JE, et al.: Characterization of frontotemporal dementia and/or amyotrophic lateral sclerosis associated with the GGGGCC repeat expansion in C9ORF72. Brain 2012, 135:765-783.

8. Lindquist SG, Duno M, Batbayli M, Puschmann A, Braendgaard H, Mardosiene S, Svenstrup K, Pinborg LH, Vestergaard K, Hjermind LE, Stokholm J, Andersen BB, Johannsen P, Nielsen JE: Corticobasal and ataxia syndromes widen the spectrum of C9ORF72 hexanucleotide expansion disease. Clin Genet 2012, doi: 10.1111/j.1399-0004.2012.01903.x. [Epub ahead of print]

9. Murray ME, DeJesus-Hernandez M, Rutherford NJ, Baker M, Duara R, GraffRadford NR, Wszolek ZK, Ferman TJ, Josephs KA, Boylan KB, Rademakers R, Dickson DW: Clinical and neuropathologic heterogeneity of C9FTD/ALS associated with hexanucleotide repeat expansion in C9ORF72. Acta Neuropathol 2011, 122:673-690.

10. O'Dowd S, Curtin D, Waite AJ, Roberts K, Pender N, Reid V, O'Connell M,
Williams NM, Morris HR, Traynor BJ, Lynch T: C9ORF72 expansion in amyotrophic lateral sclerosis/frontotemporal dementia also causes parkinsonism. Mov Disord 2012, 27:1072-1074.

11. Majounie E, Renton AE, Mok K, Dopper EG, Waite A, Rollinson S, Chiò A, Restagno G, Nicolaou N, Simón-Sánchez J, van Swieten JC, Abramzon Y, Johnson JO, Sendtner M, Pamphlett R, Orrell RW, Mead S, Sidle KC, Houlden H, Rohrer JD, Morrison KE, Pall H, Talbot K, Ansorge O; Chromosome 9-ALS/ FTD Consortium; French Research Network on FTLD/FTLD/ALS; ITALSGEN Consortium; Hernandez DG, Arepalli S, Sabatelli M, et al.: Frequency of the C9orf72 hexanucleotide repeat expansion in patients with amyotrophic lateral sclerosis and frontotemporal dementia: a cross-sectional study. Lancet Neurol 2012, 11:323-330.

12. Boxer AL, Mackenzie IR, Boeve BF, Baker M, Seeley WW, Crook R, Feldman H, Hsiung G-YR, Rutherford N, Laluz V, Whitwell J, Foti D, McDade E, Molano J, Karydas A, Wojtas A, Goldman J, Mirsky J, Sengdy P, Dearmond S, Miller BL, Rademakers R: Clinical, neuroimaging and neuropathological features of a new chromosome 9p-linked FTD-ALS family. J Neurol Neurosurg Psychiatry 2011, 82:196-203.

13. Luty AA, Kwok JB, Thompson EM, Blumbergs P, Brooks WS, Loy CT, DobsonStone C, Panegyres PK, Hecker J, Nicholson GA, Halliday GM, Schofield PR: Pedigree with frontotemporal lobar degeneration - motor neuron disease and Tar DNA binding protein-43 positive neuropathology: genetic linkage to chromosome 9. BMC Neurol 2008, 8:32.

14. Pearson JP, Williams NM, Majounie E, Waite A, Stott J, Newsway V, Murray A, Hernandez D, Guerreiro R, Singleton AB, Neal J, Morris HR: Familial frontotemporal dementia with amyotrophic lateral sclerosis and a shared haplotype on chromosome 9p. J Neurol 2011, 258:647-655.

15. Vance C, Al-Chalabi A, Ruddy D, Smith BN, Hu X, Sreedharan J, Siddique T, Schelhaas HJ, Kusters B, Troost D, Baas F, de Jong V, Shaw CE: Familial amyotrophic lateral sclerosis with frontotemporal dementia is linked to a locus on chromosome 9p13.2-21.3. Brain 2006, 129:868-876.

16. Simón-Sanchez J, Dopper EGP, Cohn-Hokke PE, Hukema RK, Nicolaou N, Seelaar H, de Graaf JRA, de Koning I, van Schoor NM, Deeg DJH, Smits M, Raaphorst J, van den Berg LH, Schelhaas HJ, De Die-Smulders CEM, MajoorKrakauer D, Rozemuller AJM, Willemsen R, Pijnenburg YAL, Heutink P, Van Swieten JC: The clinical and pathological phenotype of C9ORF72 hexanucleotide repeat expansions. Brain 2012, 135:723-735.

17. Hsiung G-YR, DeJesus-Hernandez M, Feldman HH, Sengdy P, Bouchard-Kerr P, Dwosh E, Butler R, Leung B, Fok A, Rutherford NJ, Baker M, Rademakers R, Mackenzie IRA: Clinical and pathological features of familial frontotemporal dementia caused by C9ORF72 mutation on chromosome 9p. Brain 2012, 135:709-722.

18. Byrne S, Elamin M, Bede P, Shatunov A, Walsh C, Corr B, Heverin M, Jordan N, Kenna K, Lynch C, McLaughlin RL, Iyer PM, O'Brien C, Phukan J, Wynne B, Bokde AL, Bradley DG, Pender N, Al-Chalabi A, Hardiman O: Cognitive and clinical characteristics of patients with amyotrophic lateral sclerosis carrying a C9orf72 repeat expansion: a population-based cohort study. Lancet Neurol 2012, 11:232-240.

19. Lillo P, Garcin B, Hornberger M, BakTH, Hodges JR: Neurobehavioral features in frontotemporal dementia with amyotrophic lateral sclerosis. Arch Neurol 2010, 67:826-830.

20. Chio A, Borghero G, Restagno G, Mora G, Drepper C, Traynor BJ, Sendtner M, Brunetti M, Ossola I, Calvo A, Pugliatti M, Sotgiu MA, Murru MR, Marrosu MG, Marrosu F, Marinou K, Mandrioli J, Sola P, Caponnetto C, Mancardi G, Mandich P, La Bella V, Spataro R, Conte A, Monsurro MR, Tedeschi G, Pisano F, Bartolomei I, Salvi F, Lauria Pinter G, et al: Clinical characteristics of patients with familial amyotrophic lateral sclerosis carrying the pathogenic GGGGCC hexanucleotide repeat expansion of C9ORF72. Brain 2012, 135:784-793.

21. Byrne S, Elamin M, Bede P, Shatunov A, Walsh C, Corr B, Heverin M, Jordan N, Kenna K, Lynch C, McLaughlin RL, lyer PM, O'Brien C, Phukan J, Wynne B, Bokde AL, Bradley DG, Pender N, Al-Chalabi A, Hardiman O: Cognitive and clinical characteristics of patients with amyotrophic lateral sclerosis carrying a C9orf72 repeat expansion: a population-based cohort study. Lancet Neurol 2012, 11:232-240.

22. Cummings JL, Mega M, Rosenberg-Thompson S, Carusi DA, Gombein J: The Neuropsychiatric Inventory: comprehensive assessment of psychopathology in dementia. Neurology 1994, 44:2308-2314.

23. Simón-Sanchez J, Dopper EGP, Cohn-Hokke PE, Hukema RK, Nicolaou N, Seelaar H, de Graaf JRA, de Koning I, van Schoor NM, Deeg DJH, Smits M, Raaphorst J, van den Berg LH, Schelhaas HJ, De Die-Smulders CEM, 
Majoor-Krakauer D, Rozemuller AJM, Willemsen R, Pijnenburg YAL, Heutink P van Swieten JC: The clinical and pathological phenotype of C9ORF72 hexanucleotide repeat expansions. Brain 2012, 135:723-735.

24. Simón-Sanchez J, Dopper EGP, Cohn-Hokke PE, Hukema RK, Nicolaou N, Seelaar H, de Graaf JRA, de Koning I, van Schoor NM, Deeg DJH, Smits M, Raaphorst J, van den Berg LH, Schelhaas HJ, De Die-Smulders CEM, MajoorKrakauer D, Rozemuller AJM, Willemsen R, Pijnenburg YAL, Heutink P, Van Swieten JC: The clinical and pathological phenotype of C9ORF72 hexanucleotide repeat expansions. Brain 2012, 135:723-735.

25. Rascovsky K, Hodges JR, Knopman D, Mendez MF, Kramer JH, Neuhaus J, van Swieten JC, Seelaar H, Dopper EGP, Onyike CU, Hillis AE, Josephs KA, Boeve BF, Kertesz A, Seeley WW, Rankin KP, Johnson JK, Gorno-Tempini ML, Rosen H, Prioleau-Latham CE, Lee A, Kipps CM, Lillo P, Piguet O, Rohrer JD, Rossor MN, Warren JD, Fox NC, Galasko D, Salmon DP, et al:. Sensitivity of revised diagnostic criteria for the behavioural variant of frontotemporal dementia. Brain 2011, 134:2456-2477.

26. Velakoulis D, Walterfang M, Mocellin R, Pantelis C, McLean C: Frontotemporal dementia presenting as schizophrenia-like psychosis in young people: clinicopathological series and review of cases. Br J Psychiatry 2009, 194:298-305.

27. Grace J, Malloy P: Frontal Systems Behavior Scale: Professional Manual. Lutz, FL: Psychological Assessment Resources Inc:; 2001

28. Piguet O: Eating disturbance in behavioural-variant frontotemporal dementia. J Mol Neurosci 2011, 45:589-593.

29. Casanova MF, Starkstein SE, Jellinger KA: Clinicopathological correlates of behavioral and psychological symptoms of dementia. Acta Neuropathol 2011, 122:117-135

30. Mendez MF, Shapira JS, Woods RJ, Licht EA, Saul RE: Psychotic symptoms in frontotemporal dementia: prevalence and review. Dement Geriatr Cogn Disord 2008, 25:206-211.

31. Urwin H, Josephs KA, Rohrer JD, Mackenzie IR, Neumann M, Authier A, Seelaar $\mathrm{H}$, van Swieten JC, Brown JM, Johannsen P, Nielsen JE, Holm IE, FReJA Consortium, Dickson DW, Rademakers R, Graff-Radford NR, Parisi JE, Petersen RC, Hatanpaa KJ, White CL, Weiner MF, Geser F, Van Deerlin VM, Trojanowski JQ, Miller BL, Seeley WW, van der Zee J, Kumar-Singh S, Engelborghs S, De Deyn PP, et al.: FUS pathology defines the majority of tau- and TDP-43negative frontotemporal lobar degeneration. Acta Neuropathol 2010, 120:33-41.

32. Le Ber I, Camuzat A, Hannequin D, Pasquier F, Guedj E, Rovelet-Lecrux A, Hahn-Barma V, van der Zee J, Clot F, Bakchine S, Puel M, Ghanim M, Lacomblez L, Mikol J, Deramecourt V, Lejeune P, la Sayette de V, Belliard S, Vercelletto M, Meyrignac C, Van Broeckhoven C, Lambert JC, Verpillat $P$, Campion D, Habert MO, Dubois B, Brice A; French Research Network on FTD/ FTD-MND: Phenotype variability in progranulin mutation carriers: a clinical, neuropsychological, imaging and genetic study. Brain 2008, 131:732-746.
33. Rademakers R, Baker M, Gass J, Adamson J, Huey ED, Momeni P, Spina S, Coppola G, Karydas AM, Stewart H, Johnson N, Hsiung G-Y, Kelley B, Kuntz K, Steinbart E, Wood EM, Yu C-E, Josephs K, Sorenson E, Womack KB, Weintraub S, Pickering-Brown SM, Schofield PR, Brooks WS, Van Deerlin VM, Snowden J, Clark CM, Kertesz A, Boylan K, Ghetti B, et al.: Phenotypic variability associated with progranulin haploinsufficiency in patients with the common 1477C $\rightarrow$ T (Arg493X) mutation: an international initiative. Lancet Neurol 2007, 6:857-868.

34. Johnson JO, Mandrioli J, Benatar M, Abramzon Y, Van Deerlin VM, Trojanowsk JQ, Gibbs JR, Brunetti M, Gronka S, Wuu J, Ding J, McCluskey L, Martinez-Lage M, Falcone D, Hernandez DG, Arepalli S, Chong S, Schymick JC, Rothstein J, Landi F, Wang Y-D, Calvo A, Mora G, Sabatelli M, Monsurrò MR, Battistini S, Salvi F, Spataro R, Sola P, Borghero G, et al.: Exome sequencing reveals VCP mutations as a cause of familial ALS. Neuron 2010, 68:857-864.

35. Bird TD, Wijsman EM, Nochlin D, Leehey M, Sumi SM, Payami H, Poorkaj $P$, Nemens E, Rafkind M, Schellenberg GD: Chromosome 17 and hereditary dementia: linkage studies in three non-Alzheimer families and kindreds with late-onset FAD. Neurology 1997, 48:949-954

36. Khan BK, Woolley JD, Chao S, See T, Karydas AM, Miller BL, Rankin KP: Schizophrenia or neurodegenerative disease prodrome? Outcome of a first psychotic episode in a 35-year-old woman. Psychosomatics 2012, 53:280-284.

37. Takada LT, Pimentel MLV, DeJesus-Hernandez M, Fong JC, Yokoyama JS, Karydas A, Thibodeau M-P, Rutherford NJ, Baker MC, Lomen-Hoerth C, Rademakers R, Miller BL: Frontotemporal dementia in a Brazilian kindred with the C9orf72 mutation. Arch Neurol 201, 69:1 149-1153.

38. Khan BK, Yokoyama JS, Takada LT, Sha SJ, Rutherford NJ, Fong JC, Karydas AM, Wu T, Ketelle RS, Baker MC, Hernandez M-D, Coppola G, Geschwind DH, Rademakers R, Lee SE, Rosen HJ, Rabinovici GD, Seeley WW, Rankin KP, Boxer AL, Miller BL: Atypical, slowly progressive behavioural variant frontotemporal dementia associated with C9ORF72 hexanucleotide expansion. J Neurol Neurosurg Psychiatry 2012, 83:358-364.

doi:10.1186/alzrt141

Cite this article as: Takada LT, Sha SJ: Neuropsychiatric features of C9orf72-associated behavioral variant frontotemporal dementia and frontotemporal dementia with motor neuron disease. Alzheimer's Research \& Therapy 2012, 4:38. 